\title{
Some physiological responses of wheat and bean to soil salinity at low matric suctions
}

\author{
Mahnaz Khatar ${ }^{1}$, Mohammad Hossein Mohammadi ${ }^{2,1}$, and Farid Shekari ${ }^{3}$ \\ ${ }^{1}$ Department of Soil Science, University of Zanjan, post code 38791-45371, Zanjan, Iran \\ ${ }^{2}$ Department of Soil Science Engineering, College of Agricultural Technology and Engineering, Faculty of Agriculture and Natural \\ Resources, University of Tehran, Karaj, Post box 451351666, Iran \\ ${ }^{3}$ Department of Agronomy and Plant Breeding, University of Zanjan, post code 38791-45371, Zanjan, Iran
}

Received May 3, 2016; accepted November 22, 2016

\begin{abstract}
A b s t r a c t. The effect of soil matric suction $(2-33 \mathrm{kPa})$ and salinity (soil solution electrical conductivity $0.7-8 \mathrm{dS} \mathrm{m}^{-1}$ for bean and 2-20 dS m-1 for wheat) on some physiological characteristics of bean and wheat in a clay loam soil under greenhouse condition was investigated. The results showed that the leaf chlorophyll content index and potassium concentration decrease under salinity stress and increase with matric suction from 2 to $33 \mathrm{kPa}$ suction for both plants. The wheat chlorophyll content index declines during the stress spell but bean chlorophyll content index remains nearly constant. The lowest values of the content of soluble sugars and the highest values of leaf proline content are observed at $2 \mathrm{kPa}$ matric suction (highest aeration stress) for bean and wheat. As matric suction increases from 2 to $6 \mathrm{kPa}$, the soluble sugars increases and proline content decreases significantly and then soluble sugars decreases and proline content increases until $10 \mathrm{kPa}$ suction, and the soluble sugars remains nearly constant at the higher matric suctions for both plants. While the electrical conductivity effect on the soluble sugars is not significant, the values of proline content for both crop increase significantly with electrical conductivity. It was shown that the aeration stress can result in more considerable and rapid physiological responses, in comparison with salinity stress. There is a strong correlation between wheat and bean chlorophyll content index and potassium concentration under salinity and aeration stresses.

$\mathrm{K}$ e y w o r d s: aeration, chlorophyll, potassium, proline, salinity, sugars
\end{abstract}

\section{INTRODUCTION}

Plants growing in the natural environment frequently undergo many abiotic stresses. The stresses decrease crop yield through changing plant physiological status and equilibriums (Gaspar et al., 2002). Salinity is an important limiting factor in crop production. During the salinity

*Corresponding author e-mail: mhmohmad@ut.ac.ir stress, the chlorophyll content decreases and, subsequently, plant growth declines (Cha-um et al., 2011). Soil salinity raises chlorophyllase activity, which leads to destruction of enzymes, weakness of the protein-pigment-lipid complex, degradation of chlorophyll molecules, inhibition of chlorophyll synthesis, and eventually decline in chlorophyll a and b (Parida et al., 2002). Cha-um et al. (2011) observed that the rice leaf osmotic potential decreases and chlorophyll content degrades under salinity stress. Since the chlorophyll $\mathrm{b}$ is more sensitive than chlorophyll $\mathrm{a}$, the chlorophyll a/b ratio increases with soil salinity (Parida et al., 2002). This consequence becomes more considerable when the plant is under salinity stress for a long time, because chlorophyll $\mathrm{b}$ is converted to chlorophyll a. Moreover, salinity stress results in a decline in nutrient uptake and imbalance of essential nutrients. For instance potassium concentration $\left(\mathrm{K}^{+} \mathrm{c}\right)$ and the $\mathrm{K} / \mathrm{Na}$ ratio decrease with salinity stress (Sholi, 2012).

Salt-affected soils exist in all continents and under almost all climatic conditions. Their distribution, however, is relatively more extensive in regions with a drainage problem or water excess. Therefore, plant growth is often affected by stresses of salinity and aeration deficit as well (Barrett-Lennard, 2003).

Aeration deficit often corresponds to soil matric suction (h) lower than the field capacity coefficient $(\mathrm{h}<10-30 \mathrm{kPa})$. Barrett-Lennard (2003) showed that leaf chlorosis (degradation of photosynthetic pigments) and senescence are the main visible responses of plants under stresses of salinity and aeration. Thus, the chlorophyll content, photosynthesis 
rate, and root and shoot biomasses decrease significantly (Drew and Sisworo, 1977). The decline in root extension is a consequence of a decrease in the uptake and balance of nutrients. Zeng et al. (2015) showed that, compared to salinity stress, the combined stress of aeration and salinity doubles the $\mathrm{Na}^{+}$concentration and decreases $\mathrm{K}^{+} \mathrm{c}$ in barley leaves by $40 \%$. These effects are influenced by soil redox potential and accumulation of $\mathrm{Mn}$ and Fe under waterlogged conditions. Therefore, hypoxia condition is not the main factor determining differential plant growth under stresses, and ion toxicities due to alteration in soil redox potential influence significantly plant physiological and agronomical responses as well.

To adapt to some abiotic stresses, plants begin to accumulate metabolites with low molecular weights such as carbohydrates, sugars, and proteins (Zhifang and Loescher, 2003). These compounds, maintain cellular turgor pressure, conserve the structure of protein and enzyme complexes, provide biosynthesis of nitrogen compounds, and finally result in plant adaptation to salinity stress (Mansour, 2000). For instance, proline content $(\mathrm{Pc})$ is an essential amino acid for primary metabolisms and increases in plant under environmental stresses such as salinity (Choudhary et al., 2005) and aeration deficit (Vartapetian and Jackson, 1997), especially in sensitive cultivars and long stress spells (Olgun et al., 2008). Under low matric suction or waterlogging, the Pc accumulation in legumes is correlated to the inverse of root porosity and aeration (Striker and Colmer, 2016) and acts as a biomolecule stabilizer, where under salinity stress, the Pc works as an osmolyte (Sami et al., 2016). Watad et al. (1983) showed that proline increases linearly with salinity after a threshold concentration $(35 \mathrm{mM} \mathrm{NaCl})$.

Aeration stress can also reduce $\mathrm{K}^{+}$uptake by roots and, consequently, decrease shoot $\mathrm{K}^{+} \mathrm{c}$. Deficit of leaf $\mathrm{K}^{+} \mathrm{c}$ can lead to a several-fold decrease in stomatal conductivity (Shabala and Pottosin, 2014).

The combined effects of aeration or soil low matric suction and salinity on plant physiological characteristics are rarely investigated in wet soil, especially in a close-saturated range to the soil field capacity (FC) and moisture content. The purposes of this study are:

- to evaluate the combined effects of soil aeration and salinity on the chlorophyll content index $(\mathrm{CCI}), \mathrm{K}^{+} \mathrm{c}, \mathrm{Pc}$, and soluble sugar (Ss) contents, at FC and higher moisture content and

- to investigate the relationship between the $\mathrm{CCI}$ and $\mathrm{K}^{+} \mathrm{c}$. The bean and wheat as two main agricultural crops with different stress resistances are selected as test plants.

We hypothesize that:

- the effect of salinity on plant physiological components is less considerable at low matric suctions and

- critical aeration porosity traditionally assumed as $0.1 \mathrm{~m}^{3}$ $\mathrm{m}^{-3}$ cannot be considered as a reliable upper limit of water uptake for all plants.

\section{MATERIALS AND METHODS}

The experiments were conducted in greenhouse conditions $\left(20 \pm 5^{\circ} \mathrm{C}\right)$ with 3 replicates in a factorial arrangement and in the main completely randomized design.

Non-saline agricultural topsoil (0-0.3 m layers) was sampled from the research field of University of Zanjan, north-western Iran. Soil particle size distribution (PSD) was determined using the hydrometer method (Gee and Or, 2002). To measure the soil water characteristic curve (SWCC), repacked small soil cores, $100 \mathrm{~cm}^{3}$ in size, were prepared in three replicates with considering the initial field bulk density. The soil water content in the lower matric suction range was gravimetrically determined at suction levels equivalent to $0.1,2,6$, and $10 \mathrm{kPa}$, respectively. The suction was created by lowering the water level of a sand box apparatus, in the middle of which the core samples were placed. The same samples were thereafter placed in a pressure plate apparatus for measuring soil water content corresponding to the suctions, equivalent to 33 and $100 \mathrm{kPa}$. In the next step, disturbed soil samples were placed in a pressure membrane apparatus for determining soil water content at suction equivalent to $200,300,500,1000$, and $1500 \mathrm{kPa}$ (Dane and Hopmans, 2002). The soil was airdried and passed through an $8 \mathrm{~mm}$ mesh sieve; then it was packed into 120 plastic pots (with $27 \mathrm{~cm}$ height and $26 \mathrm{~cm}$ diameter) with an initial field bulk density $\left(1.30 \mathrm{Mg} \mathrm{m}^{-3}\right)$. The wheat (Triticum aestivum cv. Mahdavi) and bean (Phaseoulus vulgaris $c v$. COS16) seeds were soaked in the water for $24 \mathrm{~h}$ before sowing into the soil. Ten bean seeds or fifteen wheat seeds were planted in each plastic pot. Once the seeds germinated and emerged, eight wheat and four bean plants were kept, on which the trial was continued. Soil salinity and suction treatments were begun immediately after third leaf appearance for wheat (L3) and first trifoliolate appearance for bean (V1).

The soil moisture treatments were conducted at matric suctions of 2, 6 , and $10 \mathrm{kPa}$ with homemade tension tables and at $33 \mathrm{kPa}$ matric suction with standard tensiometers. The homemade tension table consisted of a porous cap and a tube in a bottle of water with a specific base surface. There was a particular height difference between the base surface of water (as the suction regulator) and the middle of the soil surrounding the porous cap, which adjusted the value of matric suction at $2-10 \mathrm{kPa}$ to the pot soils (just as a sand box). The soils rapidly reached equilibrium after each irrigation event at a desired suction head. More details of the homemade tensiometer installation are given by Meskini et al. (2015).

The salinity treatments were applied at electrical conductivity (EC) values $0.7,2,4,6$, and $8 \mathrm{dSm}^{-1}$ for bean and 2, 4, 8, 16, and $20 \mathrm{dSm}^{-1}$ for wheat using $\mathrm{CaCl}_{2}$ and $\mathrm{NaCl}$ (3:1) salts as the irrigation water solution. The levels of salinity treatments of bean and wheat were selected according to the range of their resistance to salinity (FAO, 2002). 
During the experiment period, the leaf CCI was estimated with a Chlorophyll meter (CCM-200). The CCI was measured for the second matured leaf on days 30, 37, 44, and 50 after application of the treatments. At the end of the growing season, the plant green leaves were picked and used for measurements of plant Pc with the acid-ninhydrin method and a spectrophotometer apparatus (UV/VIS Perkin Elmer-Lambda 25-USA) with a wavelength of $520 \mathrm{~nm}$ (Bates et al., 1973). The plant shoots were harvested and washed with distilled water. Afterwards, the samples were dried in an oven at $70^{\circ} \mathrm{C}$ for $72 \mathrm{~h}$. The soluble sugars (Ss) in the dried samples were measured using the phenol-sulfuric acid method and a spectrophotometer apparatus (UV/ VIS Perkin Elmer-Lambda 25-USA) with a wavelength of $485 \mathrm{~nm}$ (Kochert, 1978). Also, the dried samples were digested using sulfuric acid-hydrogen peroxide (Cresser and Parsons, 1979). Finally, $\mathrm{K}^{+} \mathrm{c}$ in the extracts were measured with a flame photometer apparatus (Jenway, PFP-7, UK).

All the statistical analyses were conducted using the SAS 9.1.3 statistics software. The effect of the treatments and the interactive effects between them were investigated using Duncan multiple range test. The charts were drawn using Excel 2010 software.

\section{RESULTS AND DISCUSSION}

The soil water characteristic curve (SWCC) is depicted in Fig. 1 and some physical and chemical properties of the soil are given in Table 1.

The effects of the soil salinity and soil matric suction on the $\mathrm{CCI}, \mathrm{K}^{+} \mathrm{c}$, Ss, and Pc for wheat and bean were statistically analysed and summarized in Table 2 .

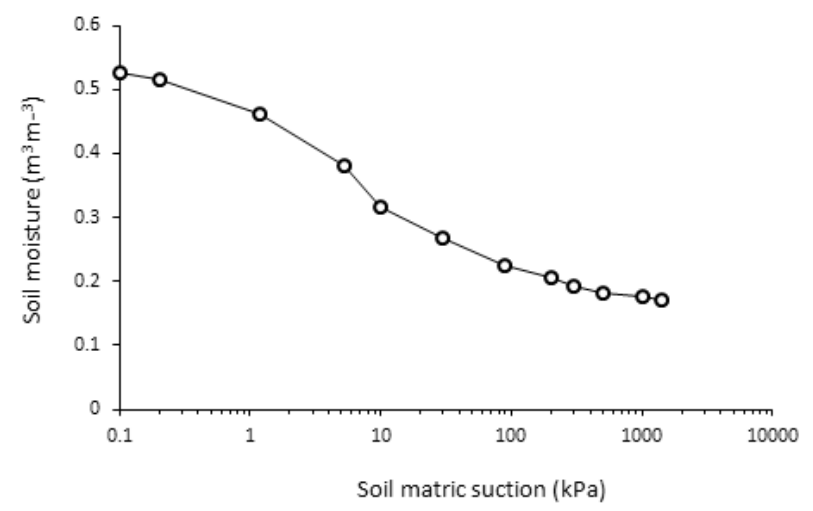

Fig. 1. Moisture characteristic curve of the soil used in the greenhouse experiment.
Variance analysis of soil EC and matric suction effects on the relative CCI of wheat and bean shows that the soil matric suction influences both bean and wheat CCI $(p<0.01)$. The statistical analysis also confirms the influences of matric suction on both bean and wheat $\mathrm{K}^{+} \mathrm{c}$, Ss, and $\mathrm{Pc}(\mathrm{p}<0.01)$. The effect of $\mathrm{EC}$ on wheat $\mathrm{K}^{+} \mathrm{c}$ and $\mathrm{Pc}$ $(p<0.01)$ is more significant than that for bean $(p<0.05)$; moreover, the EC does not influence bean Ss $(p<0.05)$. However, the effects of the EC and matric suction interaction on all the parameters are still insignificant (Table 2).

Figures 2 and 3 show the variations of wheat and bean $\mathrm{CCI}$ as a function of the soil salinity EC in different times. The CCI decreases with EC at matric suctions less than $33 \mathrm{kPa}$ for both crops. The CCI decline can be attributed to chloroplast demolition, change in the lipid/protein ratio, and an increase in the chlorophyllase and rubisco activity (Khan et al., 2016). Also, the toxic effect of some ions inhibits enzyme activity and chlorophyll synthesis in cells (Khan, 2003). The CCI-EC relationships in wheat remain approximately consistent for all matric suction (Fig. 2); however, the CCI-EC curves for different matric suctions diverge with EC during the bean growth period (Fig. 3). The salinity stress tolerance of wheat is higher than that of bean; thus, the CCI declines more rapidly for bean, especially at $2 \mathrm{kPa}$ suction (Fig. 3). Figure 1 shows that the $2 \mathrm{kPa}$ suction corresponds to the low soil aeration porosity $\left(0.08 \mathrm{~m}^{3} \mathrm{~m}^{-3}\right)$, which limits the root water and nutrient uptake in anoxia conditions (Mohammadi et al., 2010). This results in a decrease in essential nutrients for synthesis and maintaining chlorophyll and, subsequently, causes chlorophyll decay (Drew and Sisworo, 1977). Comparison of Figs 2 and 3 shows that the wheat CCI is less affected than that the bean CCI by low aeration ( $2 \mathrm{kPa}$ suction), because wheat can adapt itself slightly to the soil anoxia by developing aerenchyma tissues and creation of adventitious roots (Steffens and Rasmussen, 2016).

Figures 2 and 3 demonstrate that the CCI-EC curves increase with the soil matric suction for both crops. The minimum values of the the CCIs of wheat and bean are respectively $20\left(\right.$ at $\left.\mathrm{EC}=20 \mathrm{dS} \mathrm{m}^{-1}\right)$ and $5\left(\right.$ at $\left.\mathrm{EC}=8 \mathrm{dS} \mathrm{m}^{-1}\right)$ at $2 \mathrm{kPa}$ suction $\left(0.08 \mathrm{~m}^{3} \mathrm{~m}^{-3}\right.$ aeration porosity). Moreover, the maximum values of bean and wheat CCIs (50 and 30, respectively) are observed at soil matric suction of $33 \mathrm{kPa}$ $\left(0.26 \mathrm{~m}^{3} \mathrm{~m}^{-3}\right.$ aeration porosity) and the lowest soil salinity throughout the experiment period. The soil air permeability and oxygen diffusion rate are enhanced as the soil matric

T a b l e 1. Physical and chemical properties of the studied soil (Clay loam)

\begin{tabular}{ccccccc}
\hline $\begin{array}{c}\text { Silt } \\
\left(2 \times 10^{-6}-5 \times 10^{-5} \mathrm{~m}\right) \\
(\%)\end{array}$ & $\begin{array}{c}\text { Clay } \\
\left(<2 \times 10^{-6} \mathrm{~m}\right) \\
(\%)\end{array}$ & $\begin{array}{c}\mathrm{BD} \\
\left(\mathrm{Mg} \mathrm{m}^{-3}\right)\end{array}$ & $\mathrm{pH}$ & $\begin{array}{c}\mathrm{EC} \\
\left.(\mathrm{dS} \mathrm{m})^{-1}\right)\end{array}$ & $\begin{array}{c}\mathrm{N} \\
\left(\mathrm{g} \mathrm{kg}^{-1}\right)\end{array}$ & $\begin{array}{c}\mathrm{P} \\
\left(\mathrm{mg} \mathrm{kg}^{-1}\right)\end{array}$ \\
\hline 33 & 30 & 1.30 & 7.72 & 1.5 & 10 & $\begin{array}{c}\mathrm{K} \\
\left(\mathrm{mg} \mathrm{kg}^{-1}\right)\end{array}$ \\
\hline
\end{tabular}


T a b l e 2. Variance analysis of the effects of soil salinity EC and matric suction (h) on the $\mathrm{CCI}, \mathrm{K}^{+} \mathrm{c}$, Ss and Pc for bean and wheat

\begin{tabular}{|c|c|c|c|c|c|c|c|c|c|}
\hline \multirow{3}{*}{$\begin{array}{l}\text { Dependent } \\
\text { variable }\end{array}$} & \multirow{3}{*}{$\begin{array}{c}\text { Degree } \\
\text { of freedom }\end{array}$} & \multicolumn{8}{|c|}{ Mean square } \\
\hline & & \multicolumn{2}{|c|}{$\mathrm{CCI}$} & \multicolumn{2}{|c|}{$\mathrm{K}^{+} \mathrm{c}(\%)$} & \multicolumn{2}{|c|}{ Ss $\left(\mathrm{mg} \mathrm{g}^{-1} \mathrm{DW}\right)$} & \multicolumn{2}{|c|}{$\mathrm{Pc}\left(\mathrm{mg} \mathrm{g}^{-1} \mathrm{FW}\right)$} \\
\hline & & wheat & bean & wheat & bean & wheat & bean & wheat & bean \\
\hline $\mathrm{EC}$ & 4 & $58.17 *$ & $443.23 * *$ & $0.67 * *$ & $0.64^{*}$ & $0.02 *$ & 0.004 & $0.70 * *$ & $0.02 *$ \\
\hline $\mathrm{h}$ & 3 & $227.50 * *$ & $209.57 * *$ & $0.34 * *$ & $1.01 * *$ & $0.04 * *$ & $0.06^{* *}$ & $0.95^{* *}$ & $0.12 * *$ \\
\hline $\mathrm{EC} \times \mathrm{h}$ & 12 & 3.88 & 11.86 & 0.03 & 0.03 & 0.002 & 0.0007 & 0.04 & 0.001 \\
\hline Error & & 16.31 & 5.90 & 0.03 & 0.06 & 0.007 & 0.01 & 0.03 & 0.009 \\
\hline $\mathrm{CV}$ & & 11.55 & 12.65 & 10.09 & 15.35 & 15.40 & 19.15 & 37.37 & 26.69 \\
\hline
\end{tabular}

*, ** - mean significant effects at 0.01 and 0.05 levels of probability, respectively. DW - dry weight, FW - fresh weight.
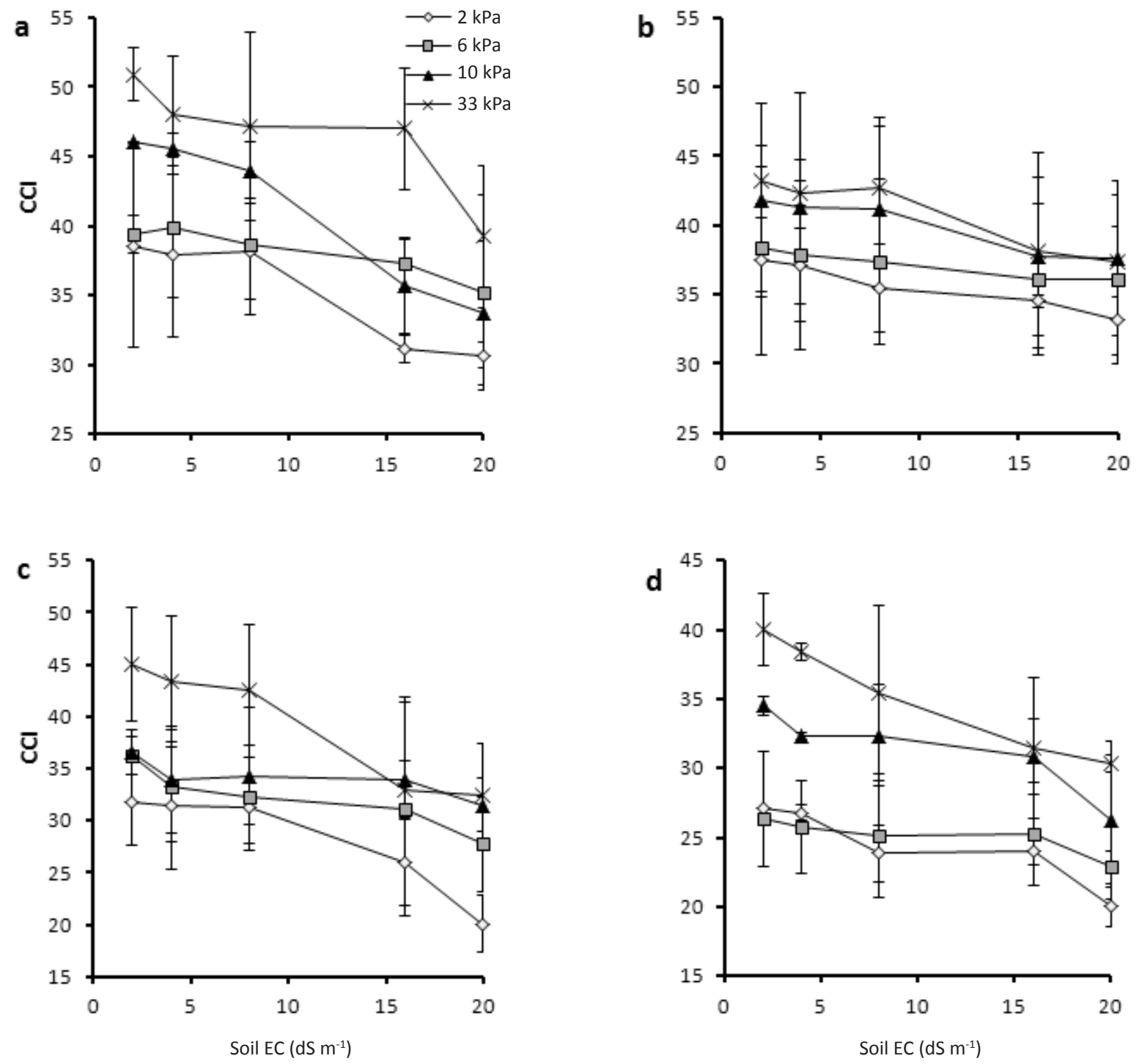

Fig. 2. Wheat leaf CCI as a function of soil salinity EC under different matric suctions, a - 30, b - 37, c - 44, and d - 55 days after treatments application. Error bars show two standard deviations of uncertainty. 

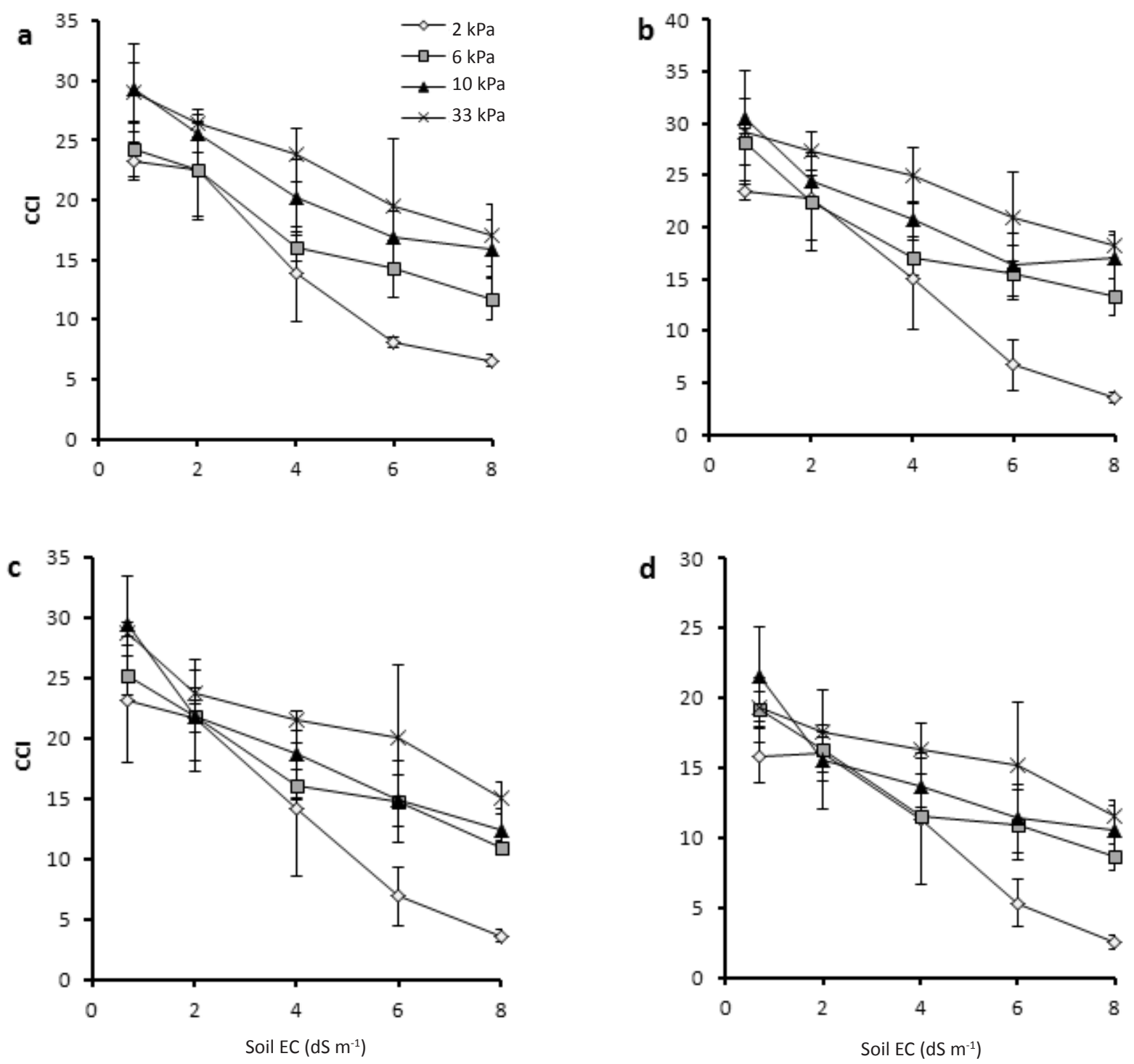

Fig. 3. Bean leaf CCI as a function of soil salinity EC under different matric suctions, $a-30, b-37, c-44$, and d - 55 days after treatments application. Error bars show two standard deviations of uncertainty.

suction increases. Thus, plant activities such as chlorophyll synthesis (and consequently CCI) improve in appropriate soil-air permeability conditions.

Depending on plant species, the anoxia effects on the chlorophyll content begin after a few hours to a few weeks (Smethurst and Shabala, 2003). Figure 2 shows that the wheat CCI decreases with time at all soil salinities and suctions treatments. The lowest wheat CCI is observed on the 55 th day after the treatments (Fig. 2 d). However, the bean $\mathrm{CCI}$ remains nearly constant during the time (Fig. 3). Since bean is sensitive to salinity stresses, its CCI is affected shortly (time course $<30$ day), while wheat CCI decreases gradually until the 55th day (Figs 2 and 3 ).

The variations of $\mathrm{K}^{+} \mathrm{c}(\%)$ as a function of the soil matric suction and soil salinity are shown in Fig. 4. The lowest wheat $\mathrm{K}^{+} \mathrm{c}(1.0 \%)$ is observed at ECs $20 \mathrm{dSm}^{-1}$
(Fig. 4a) and, similarly, the lowest bean $\mathrm{K}^{+} \mathrm{c}(0.7 \%)$ is observed at ECs $8 \mathrm{dSm}^{-1}$ (Fig. 4b) at $2 \mathrm{kPa}$ suction (low aeration). Figure 4 shows that there are almost linear increases of $0.4 \%$ in wheat $\mathrm{K}^{+} \mathrm{c}$ and $0.5 \%$ in bean $\mathrm{K}^{+} \mathrm{c}$ between suctions 2 and $33 \mathrm{kPa}$. The decline in $\mathrm{K}^{+} \mathrm{c}$ at low aeration $(\mathrm{h}=2 \mathrm{kPa})$ can be attributed to changes in solute movement across cell membranes, cell membrane potentials, and water and nutrient uptake (Chang and Loomis, 1945). Moreover, soil salinity reduces $\mathrm{K}^{+} \mathrm{c}$ at all soil matric suctions. Since the soil available water for plants decreases with salinity, the uptake of nutrients such as $\mathrm{K}^{+} \mathrm{c}$ is influenced (Chaum et al., 2011).

Figure 5 shows the relationships between the $\mathrm{K}^{+} \mathrm{c}$ and the CCI for wheat and bean. The strong correlation coefficients $(\mathrm{r}=0.79-0.88)$ between the $\mathrm{K}^{+} \mathrm{c}$ and the CCI with high linear slope values (21.8-19.6) demonstrate a considerable 

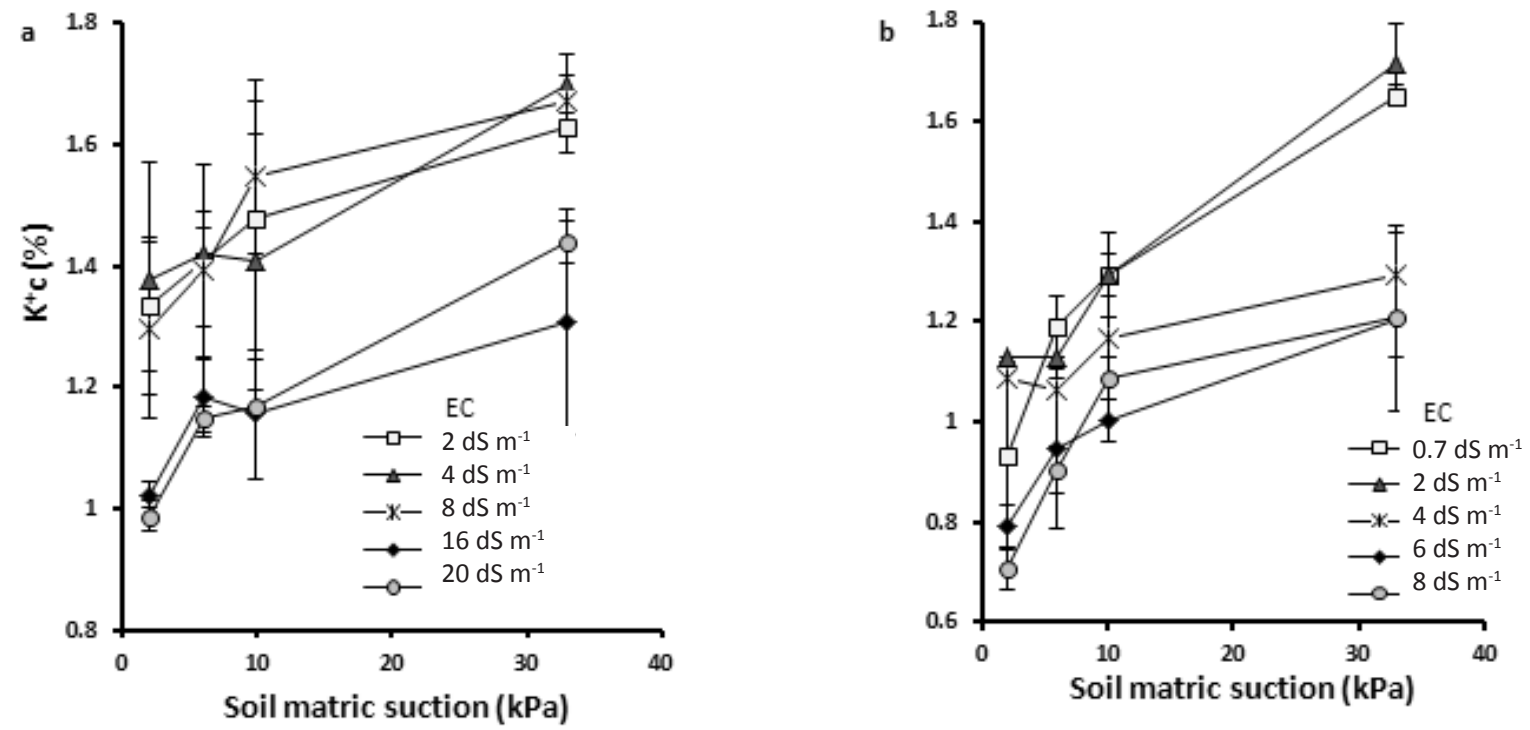

Fig. 4. Wheat (a) and bean (b) leaf $\mathrm{K}^{+}$concentration (\%) as a function of soil matric suctions under different salinities EC. Error bars show two standard deviations of uncertainty.
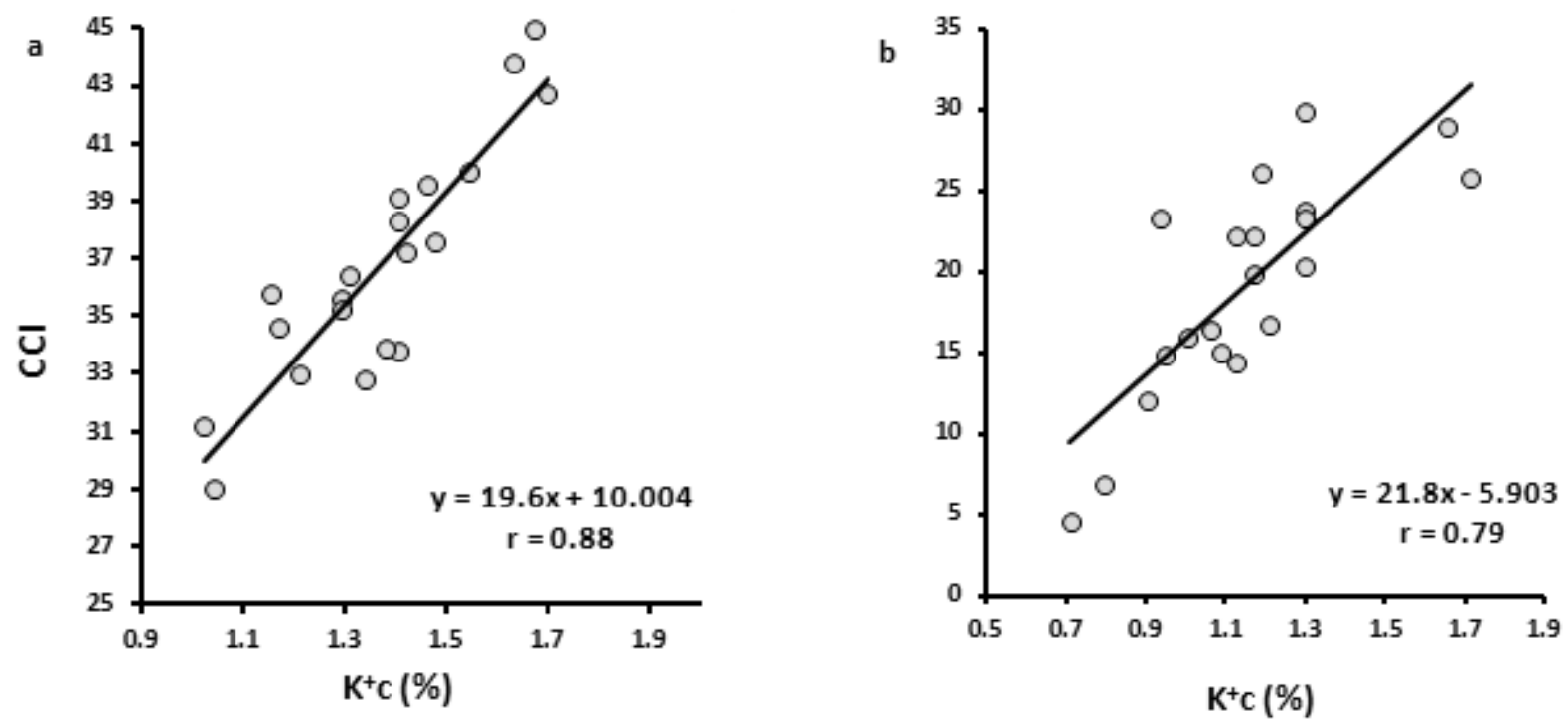

Fig. 5. Variation of: $\mathrm{a}$ - wheat and $\mathrm{b}$ - bean leaf $\mathrm{CCI}$ as a function of $\mathrm{K}^{+}$concentration $(\%)$.

effect of the $\mathrm{K}^{+} \mathrm{c}$ on the CCI. Many investigators have found that the deficiency of $\mathrm{K}^{+} \mathrm{c}$ results in chlorophyll breakdown, development of brown spots, and leaf necrosis (Pfluger, and Mengel, 1972).

Figure 6 shows the effect of the soil matric suction on the soluble sugar content Ss under different soil salinities. The minimum values of wheat and bean Ss are about $0.4 \mathrm{mg} \mathrm{g}^{-1} \mathrm{DW}$ at $2 \mathrm{kPa}$ suction for all soil salinities. At low matric suction of soil $(2 \mathrm{kPa})$, gas diffusion and transfer is insufficient for aerobic respiration; thus, plants supply their energy demand through fermentation of sugars (Saglio, 1985) and, subsequently, the Ss decrease in both wheat and bean (Fig. 6). The Ss decline can also be attributed to a decrease in metabolic activity and transfer of carbohydrates from roots (Saglio, 1985). Moreover, under anoxia conditions, the photosynthetic rate in plants and, subsequently, the content of sugars decrease significantly (Peterson and Bazzaz, 1984). As the soil suction increases from 2 to $6 \mathrm{kPa}$, aeration improves, and anaerobic respiration and fermentation of sugars becomes insignificant and the average values of Ss reach a peak at $0.57 \mathrm{mg} \mathrm{g}^{-1} \mathrm{DW}$ for wheat and at $0.64 \mathrm{mg} \mathrm{g}^{-1} \mathrm{DW}$ for bean at $6 \mathrm{kPa}$ matric suction. This matric suction corresponds with aeration porosity of $0.16 \mathrm{~m}^{3} \mathrm{~m}^{-3}$ (Fig. 1), where there is a balance between the amount of water and air, resulting in reasonable respiration and water uptake as well.

Figure 6 shows that the mean wheat and bean Ss decrease, respectively, to 0.48 and $0.55 \mathrm{mg} \mathrm{g}^{-1} \mathrm{DW}$ at matric suction of $10 \mathrm{kPa}$ and then remain nearly constant at higher suctions $(\mathrm{h}>10 \mathrm{kPa})$ for wheat. However, there is 
a

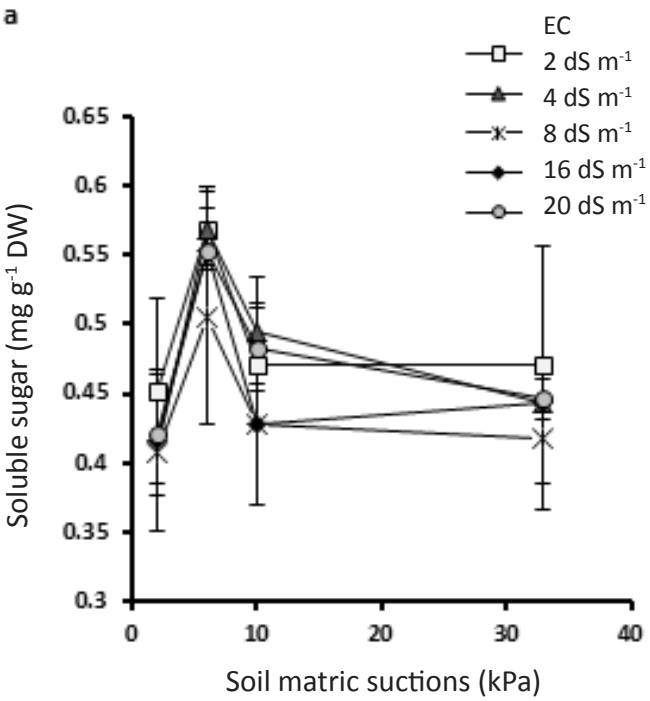

b

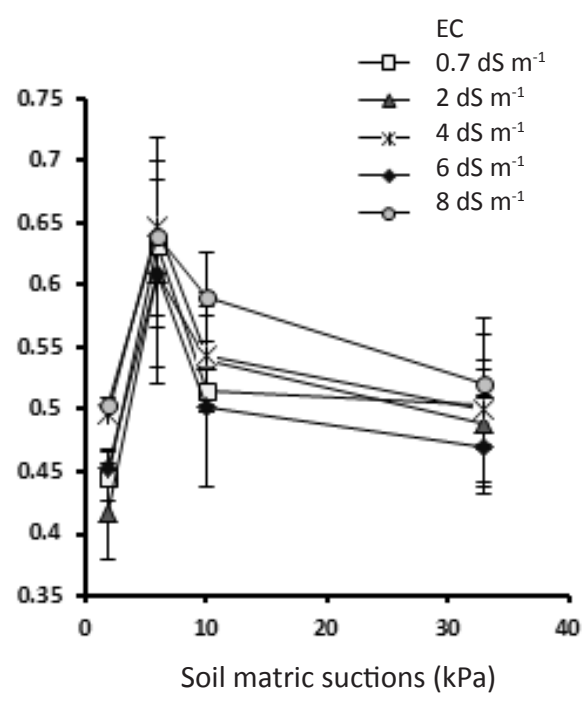

Fig. 6. Wheat (a) and bean (b) leaf soluble sugar concentration, Ss ( $\mathrm{mg} \mathrm{g}^{-1} \mathrm{DW}$ ) as a function of soil matric suctions under different salinities EC. Error bars show two standard deviations of uncertainty.

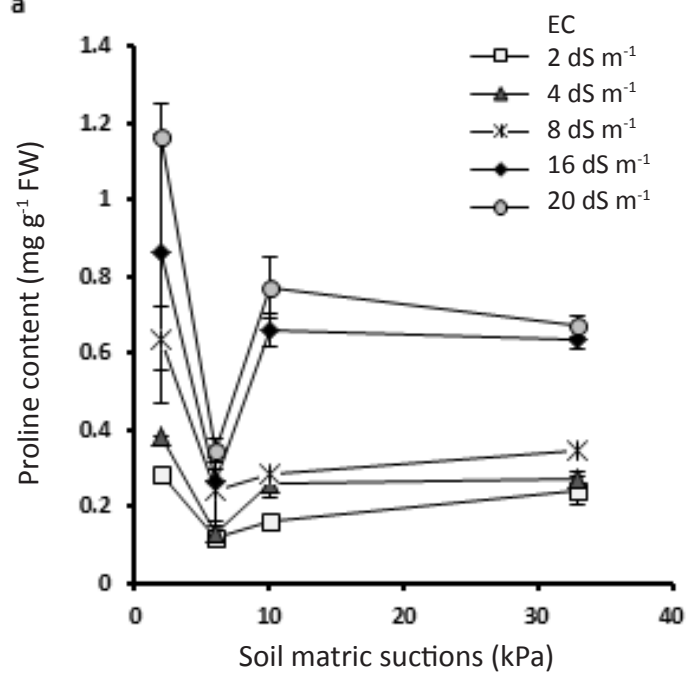

b

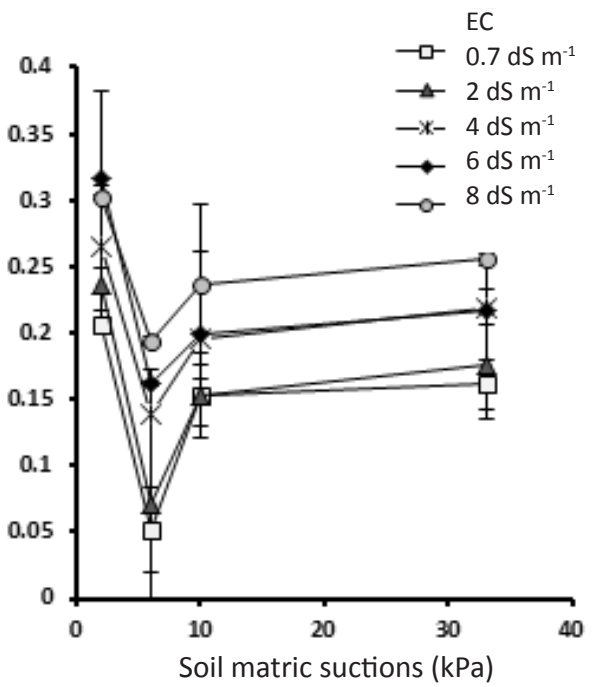

Fig. 7. Proline content of: $\mathrm{a}$ - wheat and $\mathrm{b}$ - bean $\left(\mathrm{mg} \mathrm{g}^{-1} \mathrm{FW}\right)$ as a function of soil matric suctions under different salinities EC. Error bars show two standard deviations of uncertainty.

a slight decrease of about $0.04 \mathrm{mg} \mathrm{g}^{-1} \mathrm{DW}$ in Ss between 10 and $33 \mathrm{kPa}$ matric suction for bean (Fig. 6b). The EC effect on the Ss is not consistent for both wheat and bean (Fig. 6).

Figure 7 shows the variation of the proline content as a function of soil matric suction and salinity. The highest values of the Pc are observed at the lowest matric suction $(2 \mathrm{kPa})$ and the highest soil salinity $\left(\mathrm{EC}=20 \mathrm{dS} \mathrm{m} \mathrm{m}^{-1}\right.$ for wheat and $\mathrm{EC}=8 \mathrm{dS} \mathrm{m}^{-1}$ for bean). Proline is a regulatory molecule accumulated in plants growing under stress conditions (Kaya et al., 2006). We can conclude that the aeration stress occurring at $2 \mathrm{kPa}$ suction results in a partial rise in the proline content and the salinity stress, which is considerable at higher ECs, amplifies the effect of aeration stress and leads to greater proline accumulation in bean and wheat. Figure 8 demonstrates the salinity effect on Pc at different soil suction heads and confirms the synergic effect of aeration and salinity stresses. The lowest values of Pc $\left(0.1 \mathrm{mg} \mathrm{g}^{-1} \mathrm{FW}\right.$ for wheat and $0.05 \mathrm{mg} \mathrm{g}^{-1} \mathrm{FW}$ for bean) are observed at the lowest salinity level at $6 \mathrm{kPa}$ matric suction. The decrease in Pc with aeration improvement has been observed by many researchers (Carter et al., 2006). The Pc increases with matric suctions between 6 and $10 \mathrm{kPa}$ and then remains nearly constant, for both crops. Overall, the variation of $\mathrm{Pc}$ with matric suction is conversely comparable with the variation of Ss with the matric suction. 

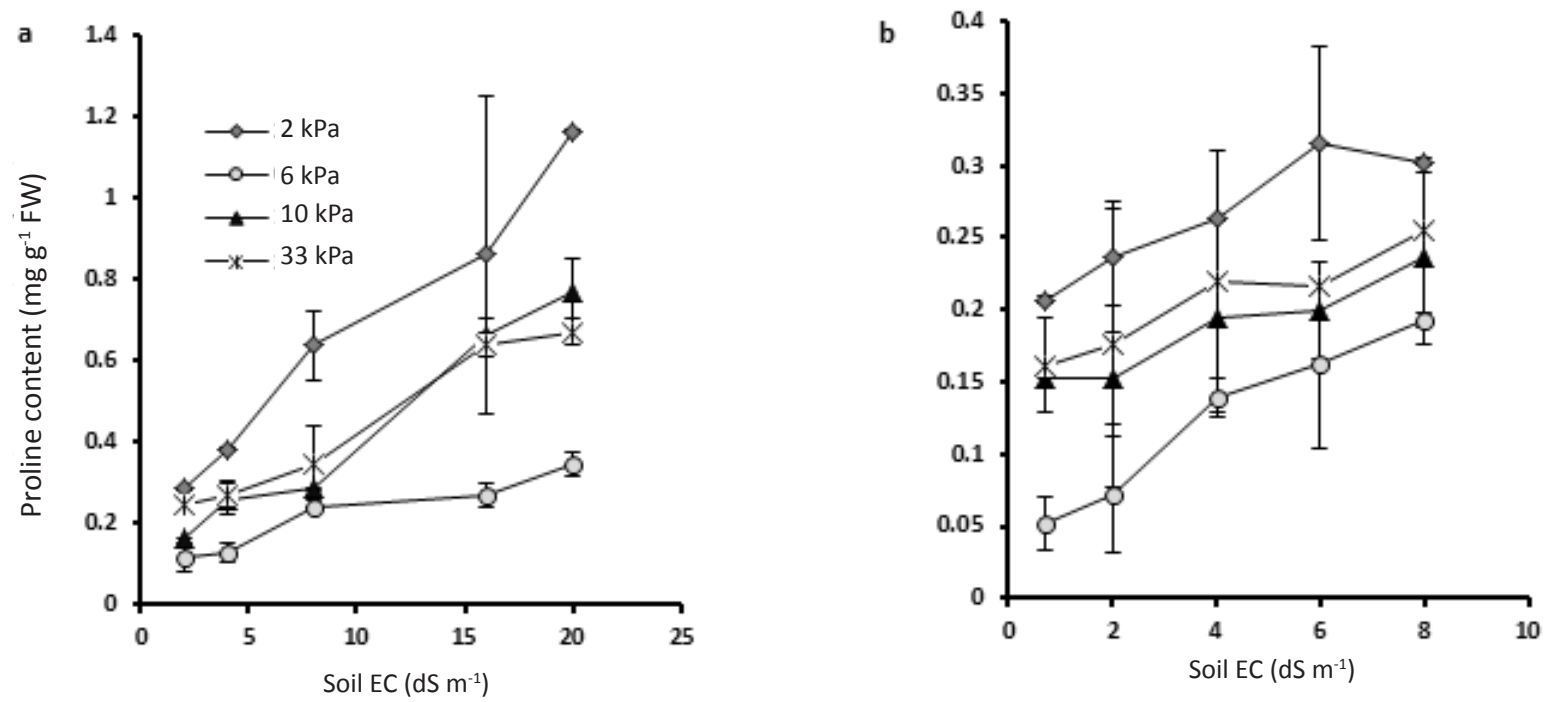

Fig. 8. Proline content of: $\mathrm{a}$ - wheat and $\mathrm{b}$ - bean $\left(\mathrm{mg} \mathrm{g}^{-1} \mathrm{FW}\right)$ as a function of soil salinity EC under different matric suctions. Error bars show two standard deviations of uncertainty.

Wheat and bean Pc increase almost linearly with the soil EC (Fig. 8). The Pc-EC relationships in bean remain approximately consistent for all matric suctions; however, the wheat Pc-EC curves for different matric suctions diverge with EC (Fig. 8).

\section{CONCLUSIONS}

1. In the wet saline soil, the wheat and bean physiological characteristics are influenced by both the aeration porosity and soil salinity. However, the relative importance of these stress factors depends on the stress level; anoxia conditions may result in more rapid and considerable responses.

2. At low aeration porosity, potassium concentration, chlorophyll content index, and soluble sugar decrease and proline content increases severely and salinity amplifies the effect of the aeration stress.

3. The highest values of soluble sugar and the lowest values of proline content are observed at aeration porosity of $0.16 \mathrm{~m}^{3} \mathrm{~m}^{-3}$.

4. The critical aeration porosity traditionally assumed as $0.1 \mathrm{~m}^{3} \mathrm{~m}^{-3}$ cannot be considered as a reliable upper limit of water uptake for all plants.

5. There are high correlations between the salinity stress and the proline content, potassium concentration and chlorophyll content index.

6. There are high correlations between the chlorophyll content index and the potassium concentration where the slope of the best lines are dependent on the type of plant.

7. Comparison of the two plants shows that, despite the sensitivity variations, their physiological responses to soil salinity and matric suction are consistent.
Conflict of interest: The Authors do not declare conflict of interest.

\section{REFERENCES}

Barrett-Lennard E.G., 2003. The interaction between waterlogging and salinity in higher plants: causes, consequences and implications. Plant Soil, 253, 35-54.

Bates L.S., Waldern R.P., and Tear I.D., 1973. Rapid determination of free proline for water stress studies. Plant Soil, 39, 205-207.

Carter J.L., Colmer T.D., and Veneklaas E.J., 2006. Variable tolerance of wetland tree species to combined salinity and waterlogging is related to regulation of ion uptake and production of organic solutes. New Phytol., 69, 123-134.

Chang H.T. and Loomis W.E., 1945. Effect of carbon dioxide on absorption of water and nutrients by roots. Plant Physiol., 20, 221-232.

Cha-um S., Pokasombat Y., and Kirdmanee C., 2011. Remediation of salt-affected soil by gypsum and farmyard manure - importance for the production of Jasmine rice. Aust. J. Crop Sci., 5, 458-465.

Choudhary N.L., Sairam R.K., and Tyagi A., 2005. Expression of delta1-pyrroline-5-carboxylate synthetize gene during drought in rice (Oryza sativa L.). Ind. J. Biochem. Biophys., 42, 366-370.

Cresser M.S. and Parsons J.W., 1979. Sulfuric per chloric acid digestion of plant material for the determination of nitrogen, phosphorus, potassium, calcium, and magnesium. Anal. Chem. Acta, 109, 431-436.

Dane J.H. and Hopmans J., 2002. Water retention and storage. In: Methods of soil analysis. Physical Methods. Soil Sci. Soc. Am., Book Series Madison, USA.

Drew M.C. and Sisworo E.J., 1977. Early effects of flooding on nitrogen deficiency and leaf chlorosis in barley. New Phytol., 79, 567-571. 
FAO, 2002. Agricultural drainage water management in arid and semi-arid areas. Annex 1. Crop salt tolerance data. FAO, Rome.

Gaspar T., Franck T., Bisbis B., Kevers C., Jouve L., Hausman J.F., and Dommes J., 2002. Concepts in plant stress physiology. Application to plant tissue cultures. Plant Growth Regul., 37, 263-285.

Gee G.W. and Or D., 2002. Particle-size analysis. In Dane JH, and Topp GC (Ed.) Methods of soil analysis. Part 4. Book Ser. 5. Soil Sci. Soc. Am., Madison WI, USA.

Kaya C., Tuna A.L., Ashraf M., and Altunlu H., 2006. Improved salt tolerance of melon (Cucumis melo L.) by the addition of proline and potassium nitrate. Environ. Exp. Botany, 6, 397403.

Khan N.A., 2003. NaCl- inhibited chlorophyll synthesis and associated changes in ethylene evolution and antioxidative enzyme activities in wheat. Biol. Plant, 47, 437-40.

Khan W.D., Aziz T., Hussain I., Ramzani P.M.A., and Reichenauer T.G., 2016. Silicon: A beneficial nutrient for maize crop to enhance photochemical efficiency of photosystem II under salt stress. Arch. Agron. Soil Sci., doi.org/1 $0.1080 / 03650340.2016 .1233322$.

Kochert G., 1978. Carbohydrate determination by the phenol sulfuric acid method. In: Hand book of phycologia method (Ed. J.A. Helebust, J.S. Craig). Cambridge University Press, Cambridge, USA.

Mansour M.M.F., 2000. Nitrogen containing compounds and adaptation of plants to salinity stress. Plant Biol., 43, 491-500.

Meskini-Vishkaee F., Mohammadi M.H., Neyshabouri M.R., and Shekari F., 2015. Evaluation of canola chlorophyll index and leaf nitrogen under wide range of soil moisture. Int. Agrophys., 29, 83-90.

Mohammadi M.H., Asadzadeh F., and Vanclooster M., 2010. Refining and unifying the upper limits of the least limiting water range using soil and plant properties. Plant Soil, 341, 241-256.

Olgun M., Kumlay A.M., Adiguzel M.C., and Caglar A., 2008. Effects of waterlogging in wheat (T. aestivum L.). Acta Agric. Scandinavica, (Section B). Plant Soil, 58, 193-198.

Parida A., Das A.B., and Das P., 2002. $\mathrm{NaCl}$ stress causes changes in photo-synthetic pigments, proteins and other metabolic components in the leaves of a tree mangrove, Bruguiera parviflora, in hydroponic cultures. J Plant Biol., 45, 28-36.
Peterson D.L. and Bazzaz F.A., 1984. Photosynthetic and growth responses of silver maple (Acer saccharinum L.) seedlings to flooding. Am. Mid. Natur., 112, 262-272.

Pfluger R. and Mengel K., 1972. Photochemical activity of chloroplasts from different plants fed with potassium. Plant Soil, 36, 417-425.

Saglio P.H., 1985. Effect of path or sink anoxia on sugars translocation in roots of maize seedlings. Plant Physiol., 77, 285-290.

Sami F., Yusuf M., Faizan M., Faraz A., and Hayat S., 2016. Role of sugars under abiotic stress. Plant Physiol. Biochem., 109, 54-61.

Shabala S. and Pottosin I., 2014. Regulation of potassium transport in plants under hostile conditions: implications for abiotic and biotic stress tolerance. Physiol. Plantar., doi: 10.1111/ppl.12165

Sholi N.J.Y., 2012. Effect of salt stress on seed germination, plant growth, photosynthesis and ion accumulation of four tomato cultivars. Am. J. Plant. Physiol., 7, 269-275.

Smethurst C.F. and Shabala S., 2003. Screening methods for waterlogging tolerance in lucerne: comparative analysis of waterlogging effects on chlorophyll fluorescence, photosynthesis, biomass and chlorophyll content. Funct. Plant Biol., 30, 335-343.

Steffens B. and Rasmussen A., 2016. The Physiology of Adventitious Roots. Plant Physiol., 170, 603-617.

Striker G.G. and Colmer T.D., 2016. Flooding tolerance of forage legumes. J Eex. Bot., doi:10.1093/jxb/erw239.

Vartapetian B.B. and Jackson M.B., 1997. Plant adaptations to anaerobic stress. Ann. Bot., 79, 3-20.

Watad A.E., Reinhold A.L., and Lerner H.R., 1983. Comparison between a stable $\mathrm{NaCl}$-selected Nicotiana cell line and the wild type. Plant Physiol., 73, 624-629.

Zeng F., Shabala L., Zhou M., Zhang G.P., and Shabala S., 2015. Barley responses to combined waterlogging and salinity stress: separating effects of oxygen deprivation and elemental toxicity. Frontiers Plant Physiol., 4, 313. doi: 10.3389/fpls.2013.00313

Zhifang G. and Loescher W.H., 2003. Expression of a celery mannose 6-phosphate reductase in Arabidopsis thaliana enhances salt tolerance and induces biosynthesis of both mannitol and a glucosyl-mannitol dimmer. Plant Cell Environ., 26, 275-283. 